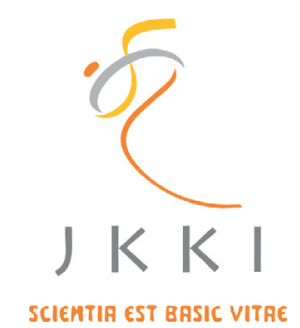

Jurnal Kedokteran dan Kesehatan Indonesia

Indonesian Journal of Medicine and Health

Journal homepage : www.journal.uii.ac.id/index.php/JKKI

\title{
Profile of medication variations and dose adjustment to diabetes mellitus patients' response in PKU Muhammadiyah hospital and Panti Rapih hospital period October-December 2014
}

\author{
Imaniar Noor Faridah*1, Dyah Aryani Perwitasari ${ }^{1}$, Desty Kusumaningsih ${ }^{2}$, Riana Prastiwi Handayani ${ }^{2}$ \\ ${ }^{1}$ Faculty of Pharmacy, Universitas Ahmad Dahlan, Yogyakarta \\ ${ }^{2}$ Student of Pharmacy, Faculty of Pharmacy, Universitas Ahmad Dahlan, Yogyakarta
}

Original Article

\begin{tabular}{|c|c|}
\hline & \\
\hline IRTICLE INFO & \multirow{5}{*}{$\begin{array}{l}\text { Background: Diabetes mellitus patients may have a different response to } \\
\text { similar medication. Therefore, individualized treatment and monitoring } \\
\text { of the therapy is needed to ensure the patients' response. Alternative } \\
\text { medication or dose adjustment should be considered in order to achieve } \\
\text { the therapeutic goal. } \\
\text { Objective: The aim of this study was to find out patients' response to } \\
\text { medication variation or dose adjustment. } \\
\text { Methods: This study used descriptive design in PKU Muhammadiyah } \\
\text { Hospital and Panti Rapih hospital period October-December } 2014 \\
\text { Participants are all patients whogotpharmacological therapy for treatment } \\
\text { of diabetes mellitus type } 2 \text {, including oral antidiabetics and/ insulin and } \\
\text { met the inclusion criteria. The response of therapy was checked } 2 \text { times } \\
\text { during check-in and check-out. } \\
\text { Results: Analysis of response variation showed that individualized } \\
\text { response existed, in which positive response occurred in } 10 \text { patients and } \\
\text { the other had a negative response. The changes were dose adjustment } \\
\text { and medication alteration or medication addition. From } 6 \text { patients who } \\
\text { needed medication adjusment, } 5 \text { patients had a positive response, and } \\
\text { others had a negative response. Whereas from } 6 \text { patients whose dosage or } \\
\text { medication was not changed, } 5 \text { of them had a positive response while one } \\
\text { had a negative response. } \\
\text { Conclusion: Individualized treatment is needed to achieve a therapeutic } \\
\text { goal. Individualized treatment can be done through dose adjustment and } \\
\text { medication alteration. or medications addition. }\end{array}$} \\
\hline & \\
\hline & \\
\hline & \\
\hline & \\
\hline
\end{tabular}

Latar Belakang: Pasien Diabetes Mellitus dapat memberikan respon yang berbeda pada pemberian obat, sehingga perlu dilakukan pengobatan secara individual, pemantauan terhadap respon pasien dan pengaturan obat atau dosis obat tersebut untuk mencapai tujuan terapi.

Tujuan: Penelitian ini bertujuan untuk mengetahui perubahan obat atau dosis yang dilakukan terhadap respon obat pada pasien diabetes mellitus.

Metode: Ini adalah penelitian deskriptif dengan subyek penelitian adalah semua pasien diabetes mellitus tipe 2 yang dirawat inap di RS PKU Muhammadiyah dan RS Panti Rapih pada bulan Oktober-Desember 2014 dan memperoleh terapi farmakologi Anti Diabetik Oral (ADO) dan/insulin serta memenuhi kriteria 
inklusi. Analisa respon pasien dilihat dalam 2 kali pemeriksaan, yaitu pada saat pasien masuk rumah sakit dan saat pasien akan pulang.

Hasil: Analisis variasi respon menunjukkan bahwa respon tiap individu berbeda, yang mana 10 pasien mengalami respon positifdan dua pasien mengalami respon negatif. Setelah dilakukan perubahan obat/ dosis tehadap 6 pasien, 5 pasien mengalami respon positif sedangkan 1 pasien mengalami respon negatif. Sementara 6 pasien yang tidak dilakukan perubahan dosis/obat, 5 pasien mengalami respon positif dan 1 pasien mengalami respon negatif.

Kesimpulan: Terapi secara individual diperlukan pada pasien diabetes mellitus, seperti melakukan pengaturan dosis atau obat, atau melakukan penambahan pengobatan untuk mencapai tujuan terapi.

\section{INTRODUCTION}

Diabetes mellitus (DM) is a multi-etiology chronic illness or disorder characterized by high blood glucose levels as well as carbohydrate, lipid, and protein metabolism disorders as a result of insulin function insufficiency. According to the International Diabetes Federation (IDF), 382 million people worldwide live with diabetes, and it is estimated that by 2035 it will increase to 592 million. This number is also expected to increase in Indonesia, in which there were 8.5 million people suffering from diabetes in 2013, and is estimated to increase to 14.1 million in 2035. ${ }^{1}$

Treatment of diabetes may utilize only one drug or a combination of two drugs. It depends on the severity of the illness and the condition of the patient, including the presence of any other illnesses or complications. ${ }^{2}$ The use of single or combination drugs in each individual will produce different effects. Some of the things that cause the variability of effects or responses come from biological factors and non-biological factors. The example of a biological factor is genetic, even though there are also non-genetic biological factors such as renal function and liver function, which will affect the pharmacokinetics of a drug. ${ }^{3}$

Several studies have shown response variation in individuals treated with antidiabetics, of which $40 \%$ had HbA1c levels above $7 \% .{ }^{4}$ In the long- term hypoglycemic drugs usage, the cumulative incidence of failure to use monotherapy for 5 years was $15 \%$ in the use of rosiglitazone, $21 \%$ in the use of metformin (biguanide) and $34 \%$ in the use of glyburide (sulfonylureas). ${ }^{5}$

The presence of different responses and effects on each individual, initiates the need for close monitoring of the patient's response. Monitoring can be done in the form of monitoring the level of treatment and monitoring the level of side effects. In the event of a change of response or unwanted effect, it is necessary to reconsider the treatment to achieve the therapeutic target. Some of the changes that can be made are changes in drug choices or its dosage. Based on these descriptions, this study was conducted to determine the effect of drug or doses alteration in achieving the desired therapeutic target.

\section{METHOD}

This research is a retrospective descriptive study, done by observing the variations of response to antidiabetic treatment using objective data through patients' blood glucose level. The research was conducted in RS PKU Muhammadiyah and RS Panti Rapih in October -December 2014.

The subjects of the study were all patients receiving pharmacological therapy for type 2 diabetes mellitus, either using oral anti diabetic (OAD) or insulin, who met the inclusion criteria. The inclusion criteria in this study were patients over the age of 18 years old who was hospitalized with a diagnosis of type 2 diabetes mellitus, supported by laboratory data of random blood glucose (RBG), as well as patients who had complete data of diabetes mellitus treatment in the medical record. Patients were excluded if they were new patients diagnosed with diabetes mellitus and had only consumed antidiabetic drug for less than 6 months.

Data collected were patients' sociodemographic data which was obtained from patients' records, data of diabetes mellitus treatment and clinical data associated with diabetes, such as RBG. The sociodemographic data included patient's age and gender. 
Treatment data included drug name, dosage, frequency, and delivery route. And the clinical data was patients' random blood glucose (RBG) which was assessed twice, once when a patient entered the hospital and once when a patient was discharged.

The analysis conducted in this research included the analysis of patient characteristics and the analysis of treatment response due to changes in the drug or dosage. Analysis of patient characteristics (age, sex and use of DM drugs) was done in percentage. While the analysis of treatment response was done by analyzing RBG changes that occurred between examinations. Response was said to be positive if patient's blood sugar levels decrease after the usage of antidiabetics. Response was considered negative if patient's blood sugar levels remain the same or increase after the usage of antidiabetics. The response was then associated with changes made to the type of medications or dosage.

\section{RESULTS \\ Patients' Characteristic}

There were 12 patients who were included in this study, 6 female patients and 6 male patients. The results of patients' characteristics can be seen in Table 1. Only a small number of patients was obtained due to a lack of complete data available. This study required complete data in

Table 1. Diabetes mellitus patients characteristic in PKU hospital Muhammadiyah and RS Panti Rapih in October-December 2014

\begin{tabular}{lc}
\hline \multicolumn{1}{c}{ Characteristic } & Total (\%) \\
\hline Gender & $6(50)$ \\
Female & $6(50)$ \\
Male & \\
Age & $11(91.67)$ \\
$40-60$ years old & $1(8.33)$ \\
$\quad>60$ years old & \\
Antidiabetic regiment & $6(50)$ \\
Monotherapy & $6(50)$ \\
Combination & \\
\hline
\end{tabular}

Table 2. Alteration of drugs and dosage to DM patients response in PKU hospital Muhammadiyah and RS Panti Rapih in October-December 2014

\begin{tabular}{llccc}
\hline No & \multicolumn{1}{c}{ Alterations } & \multicolumn{2}{c}{ Patient response } & \\
& & $\begin{array}{c}\text { Positive } \\
\text { response }\end{array}$ & $\begin{array}{c}\text { Negative } \\
\text { response }\end{array}$ & Total \\
\hline 1. & Dosage changes & - & 1 & 1 \\
2. & Medication changes & 1 & - & 1 \\
3. & Medication addition & 1 & - & 1 \\
4. & Dosage changes \& medication add & 2 & - & 2 \\
5. & Medication changes \& addition & 1 & - & 1 \\
6. & No change & 5 & 1 & 6 \\
\hline & Total & 10 & 2 & 12 \\
\hline
\end{tabular}


Table 3. Patient response analysis and alterations dose in diabetes mellitus patients In RS PKU Muhammadiyah and RS Panti Rapih in October-December 2014

\begin{tabular}{|c|c|c|c|c|c|c|}
\hline $\begin{array}{c}\text { No. } \\
\text { Patients }\end{array}$ & $\begin{array}{c}\text { Initial } \\
\text { medication }\end{array}$ & RBG & Final medication & RBG & Response & Analysis Results \\
\hline \multicolumn{7}{|c|}{ Biguanids } \\
\hline 3 & $\begin{array}{l}\text { Metformin } 2 \times 500 \\
\text { mg + insulin } \\
\text { aspart 15-0-15 }\end{array}$ & $\begin{array}{l}293 \\
\mathrm{mg} / \mathrm{dL}\end{array}$ & $\begin{array}{l}\text { Metformin } 2 \times 500 \\
\text { mg + insulin aspart } \\
15-0-15\end{array}$ & $\begin{array}{l}176 \\
\mathrm{mg} / \mathrm{dL}\end{array}$ & + & No alterations \\
\hline 6 & $\begin{array}{l}\text { Metformin } 3 \times 500 \\
\text { mg + insulin } \\
\text { Lispro } 3 \times 10 \mathrm{U}\end{array}$ & $\begin{array}{l}346 \\
\mathrm{mg} / \mathrm{dL}\end{array}$ & $\begin{array}{l}\text { Metformin 3x500 } \\
\text { mg + insulin Lispro } \\
3 \times 12 \mathrm{U}+\text { pioglitazon } \\
15 \mathrm{mg} 1 \mathrm{x} 1\end{array}$ & $\begin{array}{l}180 \\
\mathrm{mg} / \mathrm{dL}\end{array}$ & + & $\begin{array}{l}\text { Increased } \\
\text { insulin dosage } \\
\text { and addition of } \\
\text { pioglitazon }\end{array}$ \\
\hline \multicolumn{7}{|c|}{ Sulphonyilurea } \\
\hline 1 & $\begin{array}{l}\text { Glimepirid } 1 \times 2 \\
\text { mg }\end{array}$ & $\begin{array}{l}327 \\
\mathrm{mg} / \mathrm{dL}\end{array}$ & Glimepirid 1x2 mg & $\begin{array}{l}129 \\
\mathrm{mg} / \mathrm{dL}\end{array}$ & + & $\begin{array}{l}\text { No alterations of } \\
\text { drug or dosage, but } \\
\text { response changed }\end{array}$ \\
\hline 10 & $\begin{array}{l}\text { Glimepirid 1x1 + } \\
\text { Metformin 2x1 }\end{array}$ & $\begin{array}{l}339 \\
\mathrm{mg} / \mathrm{dL}\end{array}$ & $\begin{array}{l}\text { Glimepirid 1x1 + } \\
\text { Metformin 2x1 }\end{array}$ & $\begin{array}{l}131 \\
\mathrm{mg} / \mathrm{dL}\end{array}$ & + & $\begin{array}{l}\text { No alterations of } \\
\text { drug or dosage, but } \\
\text { response changed }\end{array}$ \\
\hline \multicolumn{7}{|c|}{ DPP4 Inhibitor } \\
\hline 2 & Linagliptin 1x1 & $\begin{array}{l}120 \\
\mathrm{mg} / \mathrm{dL}\end{array}$ & Linagliptin $1 x 1$ & $\begin{array}{l}161 \\
\mathrm{mg} / \mathrm{dL}\end{array}$ & - & $\begin{array}{l}\text { No alterations, but } \\
\text { RBG increased }\end{array}$ \\
\hline \multicolumn{7}{|c|}{ Thiazolidindion } \\
\hline 4 & Pioglitazon 1x1 & $\begin{array}{l}318 \\
\mathrm{mg} / \mathrm{dL}\end{array}$ & $\begin{array}{l}\text { Pioglitazon } 1 \times 1+ \\
\text { Insulin Lispro } 3 \times 12 \\
\text { U }\end{array}$ & $\begin{array}{l}122 \\
\mathrm{mg} / \mathrm{dL}\end{array}$ & + & $\begin{array}{l}\text { Addition of } \\
\text { medications, } \\
\text { change in response } \\
\text { was noted }\end{array}$ \\
\hline \multicolumn{7}{|l|}{ Insulin } \\
\hline 5 & $\begin{array}{l}\text { Insulin Aspart + } \\
\text { Insulin Glargine }\end{array}$ & $\begin{array}{l}239 \\
\mathrm{mg} / \mathrm{dL}\end{array}$ & $\begin{array}{l}\text { Insulin Aspart + } \\
\text { Insulin Glargine }\end{array}$ & $\begin{array}{l}174 \\
\mathrm{mg} / \mathrm{dL}\end{array}$ & + & $\begin{array}{l}\text { No alterations, but } \\
\text { response change } \\
\text { was noted }\end{array}$ \\
\hline 7 & $\begin{array}{l}\text { Insulin lispro } \\
3 \times 10 \mathrm{U}\end{array}$ & $\begin{array}{l}245 \\
\mathrm{mg} / \mathrm{dL}\end{array}$ & Insulin lispro $3 \times 10 \mathrm{U}$ & $\begin{array}{l}145 \\
\mathrm{mg} / \mathrm{dL}\end{array}$ & + & $\begin{array}{l}\text { No alterations, but } \\
\text { response change } \\
\text { was noted }\end{array}$ \\
\hline 8 & $\begin{array}{l}\text { Insulin Glulisin } \\
3 \times 15 \text { menit }\end{array}$ & $\begin{array}{l}442 \\
\mathrm{mg} / \mathrm{dL}\end{array}$ & $\begin{array}{l}\text { Metformin } 5003 \times 1 \\
+ \text { Insulin Glargine } \\
20-0-0\end{array}$ & $\begin{array}{l}220 \\
\mathrm{mg} / \mathrm{dL}\end{array}$ & + & $\begin{array}{l}\text { Medication and } \\
\text { dosage was } \\
\text { changed, reponse } \\
\text { also changed }\end{array}$ \\
\hline 9 & $\begin{array}{l}\text { Insulin Glulisin } \\
3 \times 15 \text { menit }\end{array}$ & $\begin{array}{l}451 \\
\mathrm{mg} / \mathrm{dL}\end{array}$ & $\begin{array}{l}\text { Insulin Aspart } \\
\text { Campuran 30-0-25 }\end{array}$ & $\begin{array}{l}110 \\
\mathrm{mg} / \mathrm{dL}\end{array}$ & + & $\begin{array}{l}\text { Drug type and } \\
\text { dosage changed }\end{array}$ \\
\hline 11 & $\begin{array}{l}\text { Insulin Aspart + } \\
\text { Campuran } 3 \times 10 \\
\mathrm{U}\end{array}$ & $\begin{array}{l}266 \\
\mathrm{mg} / \mathrm{dL}\end{array}$ & $\begin{array}{l}\text { Insulin Aspart + } \\
\text { Campuran 14-14-0 }\end{array}$ & $\begin{array}{l}434 \\
\mathrm{mg} / \mathrm{dL}\end{array}$ & - & $\begin{array}{l}\text { Drug type changed, } \\
\text { but response did } \\
\text { not }\end{array}$ \\
\hline 12 & $\begin{array}{l}\text { Novorapid 3x10 } \\
\text { U }\end{array}$ & $\begin{array}{l}378 \\
\mathrm{mg} / \mathrm{dL}\end{array}$ & $\begin{array}{l}\text { Novorapid } 3 \times 16 \mathrm{U}+ \\
\text { Metformin 1-0-1 }\end{array}$ & $\begin{array}{l}270 \\
\mathrm{mg} / \mathrm{dL}\end{array}$ & + & $\begin{array}{l}\text { Drug type and } \\
\text { dosage changed, } \\
\text { response also } \\
\text { changed }\end{array}$ \\
\hline
\end{tabular}


the form of examination results of RBG before and after treatment.

Of the 12 patients, the oldest DM patients were $40-60$ years of age $(11.67 \%)$. The treatment of DM in this study was equal between patients who use combination therapy ( 6 patients) and patients with monotherapy (6 patients).

\section{Effect of dosage or drug type changes to treatment response}

The analysis of response variation was done through drug categorization. Patients whose response variation was analyzed were those who were hospitalized because the required RBG data should be measured twice to evaluate the effect of hypoglycemic drug. The classification of patients was done based on the first drug used by patients during check-in.

The results of drug type and dosage changes can be seen in Table 2. The response was considered positive if patient's blood sugar level decrease after the use of antidiabetic. The response was considered negative if patient's blood sugar level remained or increased after the use of antidiabetic. Ten patients were found to have the positive response and 2 had the negative response, either the drug type or dosage were changed or not.

Table 3 shows that the use of medications, either oral anti diabetic (OAD) or insulin, requires individual treatment to obtain the expected results of decreased blood glucose level. Individual treatment may vary, for example drug addition, increase dosage or drug replacement. Acording to Table 3 , there were 2 patients who had a negative response where the patients blood sugar level remained higher than the initial blood glucose level.

\section{DISCUSSION}

Patients characteristics can be seen in Table 1. Patients characteristics were divided by age, gender and the use of OAD. Patients' age in this study was similar to the International Diabetes Federation data, where most diabetic patients were 40 to 59 years old. ${ }^{1}$

Treatment response in this study was seen based on changes in blood sugar levels. Treatment response was cultivated from various ways, including drug or dosage changes. It was found that the presence of hypertension, the use of sulfonylureas, the use of beta blockers, and baseline levels of $\mathrm{HbA1c}$ are related to the response of antidiabetic, while age, gender, ethnicity, duration of diabetes mellitus, dyslipidemia, and renal function disorders have no relationship with treatment response in which determined by HbA1C levels. ${ }^{11}$

Treatment response varied between individuals. Patient 2 is a patient who was treated with DPP4 inhibitor drug linagliptin which works by decreasing postprandial glucagon level and stimulates insulin secretion. Based on previous research, Linagliptin is known to be able to lower blood sugar levels in 77 patients, and reduce the number of $\mathrm{HbA} 1 \mathrm{C}$ in 4 weeks treatment. ${ }^{6}$ In patient 2 however, it is known that the patients' initial RBG level was not high, but it increased on the final RBG examination. High levels of RBG can be caused by several things, including the consumption of high-sugar food prior to the examination. Therefore, the use of linagliptin, can be continued and routine RBG examination should be performed to determine the effectiveness of linagliptin in this patient.

Patient 11 was treated with aspart insulin and mixed insulin. Insulin aspart is a type of short acting insulin with 15 minutes onset, and duration of 3 to 5 hours. During admission, the patients' blood glucose was $266 \mathrm{mg} / \mathrm{dL}$. Patient was then treated with aspart insulin and insulin mixture 3x10 U. But after therapy, patients' blood sugar levels had not stabilized, so the dose needed to be changed to $2 \times 14 \mathrm{U}$. Even after the adjusment, patients' blood glucose level still rises to $434 \mathrm{mg} / \mathrm{dL}$. According to the American Diabetes Association (2016), insulin is recommended to be used as a blood sugar controller during hospitalization, because it will ease patients' blood sugar level monitoring. High levels of RBG from patient 11 can be caused by many things, including irreguler eating and resting pattern. However, it is a limitation of this study because researchers cannot evaluate 
the exact cause and can only evaluate medical records where eating and resting patterns were not recorded. In research conducted by Huri et al. (2014), it was found that the use of insulin is not related to the response of OAD. ${ }^{11}$

Table 3 showed data that suggest the need of a strong clinical pharmacy role to monitor the therapeutic effects and the side effects of treatment. In addition to that, individualize therapy should be strengthen, including its relationship to diet, lifestyle and resting pattern. There are several aspects that can influence the response of anti diabetic drug, they are non-biological and biological aspect. Nonbiological aspects are psychological and social factors, which include patient compliance with treatment, access to health care and prescribing by doctors. The biological aspect relates to the pharmacokinetic and pharmacodynamic properties of a drug and it also relates to the genetic factors of each individual. ${ }^{3}$

Genetic factor is related to a person response to a certain medicine. For antidiabetic medications, a lot of genes play a lot of roles. Previous pharmacogenetic study had shown that gene polymorphism will influence the pathogenetic mechanism of type 2 diabetes and its treatment. ${ }^{7}$ Other study had also described the association between Multidrug and toxin extrusion 2 (MATE2-K) and low metformin reesponse, in which 2 non-synonimous variant, -c.485C $>\mathrm{T}$ and c. $1177 \mathrm{G}>\mathrm{A}$, alter metformin uptake and decrease protein expression significantly. ${ }^{8}$

Other commonly used antidiabetic in Indonesia is sulphonylurea. Based on data from the UK Prospective Diabetes Study (UKPDS) group, although many respond well to this drug, $10-20 \%$ of individuals taking this drug cannot achieve sufficient glycemic index despite taking the recommended highest dose. ${ }^{9}$ One factor that affect the use of sulphonylurea is polymorphism in KCNJ11. ${ }^{10}$

Individualized therapy needs to be done to produce the maximum therapeutic treatment by looking at the response of each individual. Individualization of therapy with pharmacogenomics is a dream to be carried out immediately, where genetically related technology is now beginning to develop and progress.

The limitation of this study is its study design, because this study is a retrospective study. Response-related analyzes should use a prospective study, in which required data such as patient's blood sugar level (GDS) or things that may affect the response can be obtained directly. In addition to that, because this research requires complete retrospective data, only a small number of patients can be analyzed.

\section{CONCLUSION}

Of the 12 patients observed, 6 patients had a drug/ dose adjustment, 5 patients had positive response while 1 patient had the negative response. The other 6 patients did not have drug/dose adjusment, 5 patients had the positive response and 1 patient had the negative response. Positive response is the decrease of patient's blood sugar level after treatment with antidiabetic. While the negative response is the increase or unchanging patient's blood sugar levels after treatment with antidiabetic.

\section{CONFLICT OF INTEREST}

We declare there is no conflict of interest

\section{ACKNOWLEDGEMENT}

Non declare

\section{REFERRENCES}

1. International Diabetes Federation. IDF Diabetes Atlas. 6th ed. International Diabetes Federation; 2013.

2. Departemen Kesehatan RI. Pharmaceutical Care Untuk Penyakit Diabetes Mellitus. Jakarta: Departemen Kesehatan RI; 2005.

3. Becker ML, Pearson ER, Tkac I. Review article : Pharmacogenetics of oral antidiabetic drugs. International Journal of Endocrinology. 2013;2013:1-10.

4. Hoeger TJ, Segel JE, Gregg EW, Saaddine JB. Is glycemic control improving in U.S. adults? Diabetes Care. 2008;31(1):81-6.

5. DiStefano JK, Watanabe RM. Review: Phar- 
macogenetics of anti-diabetes drugs. Pharmaceuticals. 2010;3(8):2610-46.

6. Huri HZ, Xiang LT. Factors associated with treatment response to antidiabetic agents in compliant Type 2 Diabetes Mellitus patients: A brief summary of 5-year data. Tropical Journal of Pharmaceutical Research. 2014;13(3):429-35.

7. Forst $\mathrm{T}$, Uhlig-Laske $\mathrm{B}$, Ring $\mathrm{A}$, Ritzhaupt A, Graefe-Mody U, Dugi KA. The oral DPP4 inhibitor linagliptin significantly lowers $\mathrm{HbA1C}$ after 4 weeks of treatment in patients with type 2 diabetes mellitus. Diabetes, Obesity and Metabolism. 2011;13(6):542-50.

8. Schroner Z, Javorsky M, Kozarova M, Tkac I. Review pharmacogenetics of oral antidiabetic treatment. Bratisl Lek Listy. 2011;112(8):441-6.

9. Choi JH, Yee SW, Ramirez AH, Morrissey KM, Jang GH, Joski PJ, et al. A common 5'-UTR variant in MATE2-K is associated with poor response to metformin. Clinical Pharmacology and Therapeutics. 2011;90(5):67484.

10. Topic E. The Role of pharmacogenetics in the treatment of Diabetes Mellitus. Journal of Medical Biochemistry. 2014;33(1):5870.

11. Acquilante CL. Sulfonylurea pharmacogenomics in Type 2 diabetes: The influence of drug target and diabetes risk polymorphisms. Expert Review of Cardiovascular Therapy. 2010;8(3):359-72. 